Southeast Asian Journal of Islamic Education Management

Vol. 1 No. 1 (2020), pp 9-23

http://sajiem.iainponorogo.ac.id/sajiem

p-ISSN: 2716-0599

e-ISSN: $2715-9604$

\title{
PENGARUH KEPEMIMPINAN KEPALA MADRASAH DAN MOTIVASI KERJA GURU TERHADAP KREATIVITAS GURU MTSN SE-KABUPATEN MADIUN
}

\author{
Kholifatul Azizah Mukhtar \\ IAIN Ponorogo, Indonesia \\ Email: Kholifatulazizahıo@gmail.com
}

DOI: https://doi.org/10.21154/sajiem.vii1.2

\begin{tabular}{|l|l|l}
\hline Received: 24 Oktober 2019 & Revised: 17 Desember 2019 & Approved: 27 Desember 2019
\end{tabular}

\section{ABSTRAK}

Artikel ini ingin menganalisis tentang pengaruh kepemimpinan kepala madrasah dan motivasi kerja guru terhadap kreativitas guru MTsN se-kabupaten Madiun. Dimana kreativitas guru dalam pembelajaran menjadi sangat penting dalam keberhasilan pembelajaran dan tujuan pendidikan di sekolah, dimana kreativitas guru sangat diperlukan agar guru dapat menjalankan tugas dan peranannya dalam proses belajar mengajar dengan maksimal. Kreativitas guru merupakan daya kreatif untuk dapat menciptakan iklim pembelajaran yang menarik dan menyenangkan sehingga tercipta suasana pembelajaran yang kondusif. Kreativitas guru juga sangat penting untuk mendorong kreativitas peserta didik, sebab dengan adanya guru yang kreatif, maka siswa juga akan belajar untuk berkreasi. Penelitian ini ingin menguji tentang pengaruh kepemimpinan kepala sekolah dan motivasi kerja guru terhadap kreativitas guru MTsN se Kabupaten Madiun. Metode penelitian yang digunakan menggunakan pendekatan penelitian kuantitaif dengan jenis penis penelitian expost-facto, sampel yang dijadikan penelitian ialah MTsN se Kabupaten Madiun dengan populasi guru PNS sebanyak 289 guru, teknik pengambilan sampel menggunakan Area Random Sampling (Cluster Sampling), yaitu pengambilan sampel secara acak dan berumpun. Hasil penelitian dalam penelitian ini ialah terdapat pengaruh yang positif dan signifikan antara kepemimpinan kepala madrasah dan motivasi kerja guru terhadap kreativitas guru Pegawai Negeri Sipil MTsN se-Kabupaten Madiun tahun pelajaran 2017/2018 yang ditunjukkan dengan hasil uji F yaitu nilai Fhitung lebih besar dari Ftabel (15,123 > 3,040). Dan pada taraf signifikan 5\% dengan koefisien determinan 0,257 sehingga dapat disimpulkan bahwa kreativitas guru dipengaruhi oleh kepemimpinan kepala madrasah dan motivasi kerja guru sebesar 25,7\%. Data hasil penelitian ini menunjukkan bahwa kepemimpinan kepala madrasah dan motivasi kerja menyumbang sebesar $25,7 \%$ dan sisanya $74,3 \%$ dipengaruhi variabel lain baik secara internal seperti rasio, bakat khusus, perasaan, dan intuisi. Maupun eksternal seperti latar belakang pendidikan guru, pelatihan-pelatihan guru, pengalaman mengajar guru, dan faktor kesejahteraan guru

Kata Kunci: Kepemimpinan Kepala Madrasah, Motivasi kerja guru, Kreativitas guru 
Southeast Asian Journal of Islamic Education Management 1 (1) 2020)

\section{PENDAHULUAN}

Perkembangan dunia pendidikan saat ini menuntut para guru untuk lebih kreatif dan produktif. Walaupun tidak dapat disangkal, saat ini masih banyak guru yang belum sampai ke tahap itu. Mereka hanya menjadi guru yang sebatas mengajar saja. ${ }^{1}$ Hal tersebut menjadi permasalahan yang dialami sebagian besar guru di negeri ini. Sedangkan menurut Muhibbin Syah arti pendidikan adalah usaha sadar untuk menumbuhkembangkan potensi sumber daya manusia (SDM) melalui pengajaran. ${ }^{2}$

Pengembangan gagasan/ide dan perilaku pembelajaran guru yang kreatif menjadi faktor penting dalam mencapai hasil pendidikan yang memadai. Dengan kreativitas guru dapat menciptakan pembelajaran yang lebih aktif, dinamis, tidak monoton dan tidak menjenuhkan siswa, sehingga siswa akan lebih bersemangat dan senang menerima pembelajaran. Kreativitas guru itu berhubungan dengan merancang dan mempersiapkan bahan ajar/materi pelajaran, mengelola kelas, menggunakan metode yang variatif, memanfaatkan media pembelajaran, sampai dengan mengembangkan instrumen evaluasi. Segenap pengembangan kreativitas ini perlu dipahami sepenuhnya oleh guru terutama mengenai penggunaan, tujuan dan hasil yang diharapkan dalam proses pembelajaran. ${ }^{3}$

Proses yang di dalam kelas mengandalkan aspek kognitif, sehingga pemahaman masih berpusat pada aspek pengetahuan dan ingatan. Anak didik hanya mendengar dan menghafalkan apa yang disampaikan guru. Proses interaksi dinamis dengan anak didik belum berjalan dengan baik, kondisi ini menghambat aktivitas dan kreativitas anak didik. Karenanya pihak guru pun dipandang perlu dalam mengembangkan kreativitas bukan hanya untuk penunjang kinerja guru saja, namun juga untuk anak didik dan dunia pendidikan. ${ }^{4}$

Kreativitas guru merupakan istilah yang banyak digunakan, baik di lingkungan sekolah maupun luar sekolah. Pada umumnya orang menghubungkan kreativitas dengan produk-produk kreasi. Dengan kata lain produk-produk kreasi itu merupakan hal yang penting untuk menilai kreativitas. Clark Monstakos, seorang psikolog humanistis menyatakan bahwa kreativitas adalah pengalaman mengekspresikan (mengaktualisasikan) identitas individu dalam bentuk terpadu dalam hubungan dengan diri sendiri, dengan alam

\footnotetext{
1 Damayanti, Sukses Menjadi Guru Humoris dan Idola (Yogjakarta: Araska, 2016), 25.

2 Muhibbin Syah, Psikologi Belajar (Jakarta: Raja Grafindo Persada, 2003), 1.

3 Iskandar Agung, Meningkatkan Kreativitas Pembelajaran Bagi Guru (Jakarta Timur: Bestari Buana Murni, 2010), 6. 4 Asmani, Sudahkah Anda Menjadi Guru Berkarisma, 150.
} 
dan orang lain. ${ }^{5}$ Memperhatikan hal tersebut, maka kreativitas guru sangat diperlukan agar guru dapat menjalankan tugas dan peranannya dalam proses belajar mengajar dengan maksimal. Kreativitas guru merupakan daya kreatif untuk dapat menciptakan iklim pembelajaran yang menarik dan menyenangkan sehingga tercipta suasana pembelajaran yang kondusif. Kreativitas guru juga sangat penting untuk mendorong kreativitas peserta didik, sebab dengan adanya guru yang kreatif, maka siswa juga akan belajar untuk berkreasi ${ }^{6}$

Apabila dalam pengajaran seorang guru tidak memiliki kreativitas, pengajaran hanya akan bersifat memberi tekanan yang membuat siswa stress, takut sekolah, membenci guru, dan seterusnya. Namun sebaliknya guru memberikan pengajaran yang kreatif yaitu lebih banyak memberikan tantangan berupa tawaran dan dorongan yang membuat siswa tertarik untuk menunjukkan kehebatan dan kebolehan dari siswa. ${ }^{7}$

Beberapa faktor yang memengaruhi kreativitas guru adalah: 1) faktor internal yang meliputi rasio/thinking, bakat khusus kemampuan bertalenta cipta/talent, perasaan/feeling, intuisi/intuitive, dan motivasi; 2) faktor eksternal terdiri dari, latar belakang pendidikan guru, pelatihan-pelatihan guru dan organisasi keguruan, pengalaman mengajar guru, faktor kesejahteraan guru, dan kepemimpinan kepala sekolah: ${ }^{8}$

Dalam suatu organisasi, faktor kepemimpinan memegang peranan yang penting karena pemimpin itulah yang akan menggerakkan dan mengarahkan organisasi dalam mencapai tujuan. Dengan kata lain sukses tidaknya usaha pencapaian tujuan organisasi ditentukan oleh kualitas kepemimpinan. ${ }^{9}$ Kepemimpinan adalah suatu kekuatan penting dalam rangka mengelola, oleh sebab itu kemampuan memimpin secara efektif merupakan kunci keberhasilan organisasi. Kepala madrasah merupakan motor penggerak penentu arah kebijakan madrasah, yang akan menentukan bagaimana tujuan-tujuan madrasah dan pendidikan pada umumnya direalisasikan. ${ }^{10}$

Melalui kepemimpinannya seorang kepala madrasah diharapkan dapat menumbuhkan kreativitas warga madrasah termasuk guru. Hal ini selaras dengan pandangan Hani Handoko yang memandang bahwa kepemimpinan sebagai kemampuan yang dimiliki

5 Utami Munandar, Kreativitas dan Keberbakatan: Strategi Mewujudkan Potensi Kreatif dan Bakat (Jakarta: Gramedia Pustaka, 2002), 24. 6 Mulyasa, Menjadi Guru Profesional, 58. 7 Hudaya Latuconsina, Pendidikan Kreatif (Jakarta: Gramedia Pustaka Utama, 2014), 207. 8 A. Samana, Profesionalisme Keguruan (Yogyakarta: Kanisius, 1994), 21. 9 Edy Sutrisno, Manajemen Sumber Daya Manusia (Jakarta: Kencana, 2017), 213. 1o Mulyasa, Manajemen Berbasis Sekolah (Bandung: PT Remaja Rosdakarya, 2012), 126. 
seseorang untuk memengaruhi dan menggerakkan orang lain agar bekerja dalam mencapai tujuan dan sasaran. Demikian kepala madrasah diharapkan mampu memengaruhi, menggerakkan, dan memotivasi guru dalam mengembangkan kreativitas mereka, terutama dalam meningkatkan mutu pembelajaran. ${ }^{11}$

Namun, dewasa ini semakin disadari bahwa kreativitas seorang guru tidak hanya dapat ditumbuhkan dari faktor luar diri seorang guru saja, namun juga perlu adanya daya dorong atau motivasi diri untuk lebih aktif lagi dalam mengaktualisasikan diri di lingkungannya. Sejalan dengan itu, teori lain menyatakan bahwa kreativitas merupakan titik pertemuan yang khas antara tiga atribut psikologis yaitu intelegensi, kemampuan kognitif, dan kepribadian atau motivasi. Secara bersamaan ketiga segi tersebut saling terkoneksikan di dalam pikiran dalam membantu memahami apa yang melatarbelakangi individu yang kreatif. ${ }^{12}$

Motivasi merupakan satu kekuatan yang mendorongan individu untuk melakukan sesuatu seperti yang diinginkan, atau dikehendakinya. ${ }^{13}$ Motivasi muncul karena kebutuhan. Seseorang akan terdorong untuk bertindak manakala dalam dirinya ada kebutuhan. Kebutuhan ini yang akan menimbulkan ketidakseimbangan (ketidakpuasan), yaitu ketegangan-ketegangan, dan ketegangan itu akan hilang manakala kebutuhan itu telah terpenuhi. ${ }^{14}$

Sebagai makhluk sosial manusia membutuhkan orang lain. Manusia akan berusaha memenuhi kebutuhannya dan memerlukan motivasi atau dorongan dari dalam diri maupun dari orang lain untuk mencapai apa yang menjadi tujuan hidupnya. Pemberian motivasi dengan tepat dapat menimbulkan semangat, gairah, dan keikhlasan kerja dalam diri seseorang. Meningkatnya kegairahan dan kemauan untuk bekerja dengan sukarela tersebut akan menghasilkan pekerjaan yang lebih baik, sehingga akan meningkatkan produktivitas kerja. Sedangkan orang yang memiliki motivasi rendah, mereka akan bekerja seenaknya dan tidak berusaha untuk mendapatkan hasil yang maksimal. ${ }^{15}$

Bagi guru kreativitas merupakan sesuatu yang penting untuk dimiliki, dan apabila kreativitas tidak dipupuk akan berdampak pada guru itu sendiri. Seperti yang dilansir oleh

\footnotetext{
11 Hani Handoko, Manajemen Personalia dan Sumber Daya Manusia (Yogyakarta: BPFE, 2001), 294. 12 Munandar, Kreativitas dan Keterbakatan: Strategi Mewujudkan Potensi Kreatif dan Bakat, 26. 13 Chalidjah Hasan, Dimensi-dimensi Psikologi Pendidikan (Surabaya: al-Ikhlas, 1994), 43. 14 Wina Sanjaya, Kurikulum dan Pembelajaran (Jakarta: Kencana, 2010), 251. 15 Makmun, Psikologi Pendidikan (Bandung: Remaja Rosdakarya, 2005), 56.
} 
redaksi Kompas, bahwa dalam kurun waktu 10 tahun terakhir total guru yang belum mendapatkan tunjangan profesi mencapai 656.150 orang. Sebagian besar guru merasa kesulitan memenuhi syarat-syarat karena masih banyak guru yang belum berkualifikasi pendidikan sarjana $\left(\mathrm{S}_{1}\right)$ dan ada juga yang memasuki usia pensiun. Hal tersebut memicu sebagian guru mengambil jalan pintas dengan memalsukan ijazah, hal tersebut menjadi ironi keterbatasan guru dalam memecahkan masalah karier. Padahal dapat kita pahami bahwa tujuan sertifikasi guru dalam mendapatkan Tunjangan Profesi Guru (TPG) yaitu untuk meningkatkan kualitas layanan pendidikan dan untuk kesejahteraan guru sehingga mereka harus dapat meningkatkan kualitas dirinya sebagai guru. ${ }^{16}$

Berdasarkan studi pendahuluan, ditemukan bahwa dalam proses belajar mengajar ada sebagian guru yang memiliki tingkat kreativitas rendah. Hal ini ditandai dengan metode pembelajaran yang hanya ceramah saja. Disamping itu, sebagian besar guru juga kurang kreatif dalam menggunakan media pembelajaran. Keadaan ini menyebabkan beberapa siswa kurang semangat dalam mengikuti pembelajaran menjadi kurang maksimal. ${ }^{17}$ Memandang pentingnya kreativitas guru dalam meningkatkan proses dan hasil belajar serta meningkatkan karier guru maka penulis tertarik untuk melakukan penelitian tentang ada tidaknya pengaruh kepemimpinan kepala sekolah, motivasi kerja guru dan kreativitas guru.

\section{HASIL UJI INSTRUMEN}

\section{a. Uji Validitas Isi}

Validitas isi adalah derajat di mana sebuah tes mengukur cakupan subtansi yang ingin diukur. ${ }^{18}$ Validitas isi berkaitan dengan apakah item-item instrumen menggambarkan pengukuran dalam cakupan yang ingin diukur. Validitas isi pada umumnya ditentukan oleh pertimbangan tim panel ahli dalam hal ini adalah Dr. Muhammad Ali, M.Pd, Dr Muhammad Thoyib, M.Pd, dan Dr Mukhibat, M.Ag.

\footnotetext{
16 Nasib guru Sertifikasi, Kompas, $27 \quad$ Oktober 2017 , http://edisi.kompas.com/read/2017/10/27/16340051/sertifikasi-guru-bagaimana-nasibnya-kini-, di akses tanggal 21 Januari 2018

17 Pada kegiatan Pembelajaran di MTsN Balerejo, MTsN Kare, MTsN Sidorejo, Observasi, Madiun, pada bulan Januari 2018. 18 Sukardi, Metodologi Penelitian (Jakarta: Raja Grafindo, 2013), 123.
} 


\section{b. Uji Validitas Empirik}

Validitas empirik adalah validitas yang dinyatakan berdasarkan hasil pengalaman. ${ }^{19}$ Perhitungan validitas empirik instrumen kepemimpinan kepala madrasah $\left(\mathrm{X}_{1}\right)$, motivasi kerja guru $\left(\mathrm{X}_{2}\right)$, dan kreativitas guru $(\mathrm{Y})$ dibantu dengan menggunakan program SPSS Statistic Version 18. Cara menentukan valid atau tidaknya instrumen penelitian adalah dengan mengonsultasikan hasil perhitungan korelasi dengan tabel nilai koefisien korelasi Product Moment Ppearson pada taraf kesalahan/signifikansi 5\% yaitu sebesar $0,361(\mathrm{df}=30-2$ = 28). Apabila $r_{\text {hitung }}>r_{\text {tabel }}$ dengan taraf signifikansi $5 \%$ maka soal dinyatakan valid dan apabila $\mathrm{r}_{\text {hitung }}<\mathrm{r}_{\text {tabel }}$ maka soal dinyatakan tidak valid.

\section{c. Uji Realibitas}

Uji reliabilitas berhubungan dengan masalah kepercayaan. Suatu tes dapat mempunyai taraf kepercayaan yang tinggi jika tes tersebut dapat memberikan hasil yang tetap. Maka pengertian reliabilitas tes, berhubungan dengan masalah ketetapan hasil tes. ${ }^{20}$ Selanjutnya nilai Alpha dikonsultasikan dengan tabel r Product Moment, jika nilai Alpha lebih besar maka konstruk pernyataan yang merupakan dimensi variabel adalah reliabel. ${ }^{21}$

\section{Tabel Hasil Uji Reliabilitas Instrumen Penelitian}

\begin{tabular}{|l|l|l|l|}
\hline No & Variabel & $\begin{array}{l}\text { Conbach } \\
\text { Alpha }\end{array}$ & Keterangan \\
\hline $\mathbf{1}$ & Kepemimpinan Kepala Madrasah $\left(\mathrm{X}_{1}\right)$ & 0,737 & Reliabel \\
\hline $\mathbf{2}$ & Motivasi Kerja $\left(\mathrm{X}_{2}\right)$ & 0,805 & Reliabel \\
\hline $\mathbf{3}$ & Kreativitas Guru (Y) & 0,626 & Reliabel \\
\hline
\end{tabular}

Sumber: Data primer yang telah diolah

\section{Uji Prasyarat Analisis}

\section{a. Uji Normalitas}

Uji normalitas dalam penelitian ini menggunakan uji Kolmogorov-Smirnov yang dihitung dengan program SPSS statistic version 18 pada taraf signifikan sebesar 5\%. Pengambilan keputusan berdasarkan nilai probabilitas yaitu jika $>$ 0,05 maka data normal dan jika < 0,05 maka data tidak normal. Hasil uji normalitas dapat dilihat pada tabel di bawah ini:

19 Maman Abdurahman, Dasar-dasar Metode Statistik untuk Penelitian (Bandung: Pustaka Setia, 2011), 50. 20 Suharsimi Arikunto, Dasar-dasar Evaluasi Pendidikan (Jakarta: PT Bumi Aksara, 200o), 86.

21 Ibid., 112. 
Tabel Ringkasan Hasil Uji Normalitas

\begin{tabular}{|l|l|l|l|l|}
\hline No & Variabel Kepala & KS-Z & p(sig) & Keterangan \\
\hline $\mathbf{1}$ & $\begin{array}{l}\text { Kepemimpinan } \\
\text { Madrasah }\left(\mathrm{X}_{1}\right)\end{array}$ & $\mathbf{0 , 5 9 4}$ & Normal \\
\hline $\mathbf{2}$ & Motivasi Kerja Guru $\left(\mathrm{X}_{2}\right)$ & 0,942 & 0,337 & Normal \\
\hline 3 & Kreativitas Guru (Y) & $\mathbf{1 , 0 7 5}$ & 0,198 & Normal \\
\hline
\end{tabular}

Sumber: Data primer yang telah diolah

\section{b. Uji Linieritas}

Uji linieritas dilakukan untuk menguji apakah ada hubungan secara linier antara variabel bebas $(\mathrm{X})$ dengan variabel terikat $(\mathrm{Y})$. Data diolah menggunakan bantuan program komputer SPSS statistic version 18. Pengambilan keputusan melihat kriteria nilai F hitung < F tabel pada taraf signifikan $5 \%$. Selain itu, berdasarkan data yang diperoleh diketahui bahwa $P$ value untuk garis regresi $\mathrm{X}_{1}$ terhadap $\mathrm{Y}$ lebih besar dari o,05 maka gagal tolak $\mathrm{H}_{\mathrm{o}}$, artinya garis regresi $\mathrm{X}_{1}$ terhadap $\mathrm{Y}$ dan $\mathrm{X}_{2}$ terhadap $\mathrm{Y}$ linier dan memungkinkan untuk menggunakan analisis Regresi. Uji linieritas dapat disajikan dalam tabel sebagai berikut:

\section{Tabel Ringkasan Hasil Uji Linieritas}

\begin{tabular}{|l|l|l|l|l|l|}
\hline No & Variabel Bebas & $\mathbf{D f}$ & $\mathbf{F}$ & $\mathbf{F}_{\mathbf{o}, \mathbf{5}}$ & Ket \\
\hline $\mathbf{1}$ & $\begin{array}{l}\text { Kepemimpinan } \\
\text { Kepala Madrasah } \\
\left(\mathrm{X}_{1}\right)\end{array}$ & $\mathbf{2 2 : 7 2 9}$ & $\begin{array}{l}0,79 \\
4\end{array}$ & $\mathbf{1 , 5 7 0}$ & Linier \\
\hline $\mathbf{2}$ & $\begin{array}{l}\text { Motivasi Kerja } \\
\left(\mathrm{X}_{2}\right)\end{array}$ & $35: 339$ & $\mathbf{1 , 1 0 3}$ & $\mathbf{1 , 5 7 0}$ & Linier \\
\hline
\end{tabular}

Sumber: Data primer yang telah diolah

\section{c. Uji Heteroskedastisitas}

Uji heteroskedastisitas bertujuan untuk menguji apakah dalam model regresi terjadi ketidaksamaan varian dari residual satu pengamatan ke pengamatan yang lain. Jika varian dari residual satu pengamatan ke pengamatan lain tetap disebut terjadi homoskedastisitas dan jika variannya tidak sama/berbeda disebut terjadi heteroskedastisitas. Model regresi yang baik adalah yang homokedastisitas, atau tidak terjadi heteroskedastisitas. Untuk mempermudah, peneliti menggunakan bantuan program komputer SPSS statistic version 18. Dari grafik scatterplot terlihat bahwa titik-titik menyebar secara acak serta tersebar baik diatas maupun dibawah angka o pada sumbu Y. Hal ini dapat disimpulkan bahwa tidak 
terjadi heteroskedastisitas. Dan untuk mengetahui ada atau tidaknya heteroskedastisitas dalam model regresi maka perhatikan grafik di bawah ini:

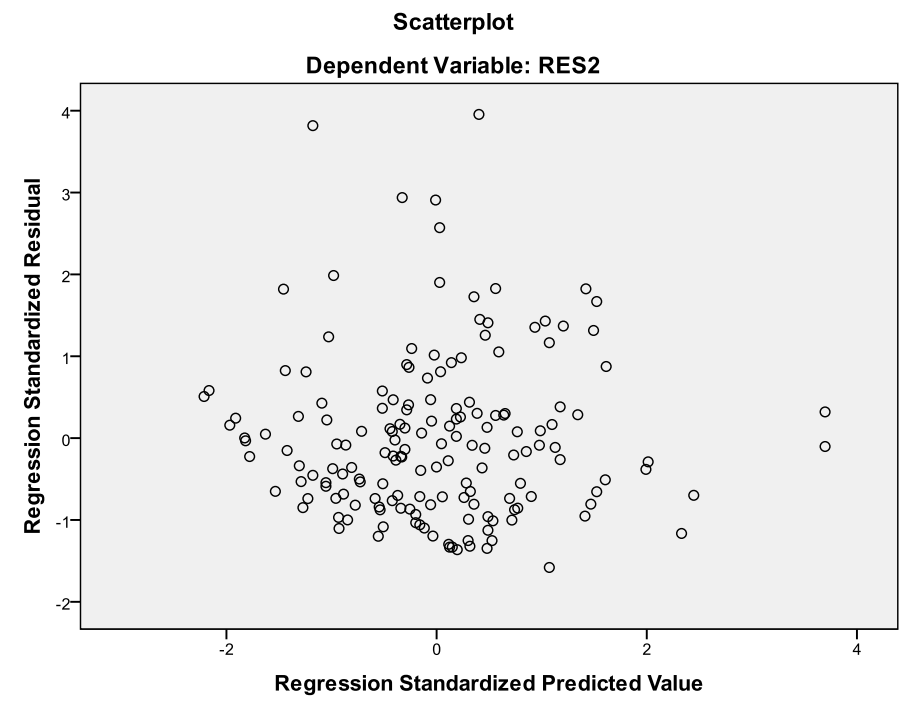

\section{Grafik Hasil Uji Heteroskedastisitas}

Sumber: Data Output SPSS

\section{d. Uji Multikolinieritas}

Uji multikolinieritas bertujuan untuk mengetahui keeratan hubungan antar variabel bebas dengan menggunakan bantuan program komputer SPSS statistic version 18. Pengambilan keputusan melihat kriteria nilai koefisien korelasi. Nilai tolerence semua variabel bebas lebih besar dari o,10 dan nilai VIF kurang dari 10,0. Dalam penelitian ini keeratan hubungan antara variabel bebas sebesar o,240 atau tidak melebihi o,6oo. Dengan demikian tidak terjadi multikolinieritas karena tidak melebihi o,6oo, yang berarti tidak ada hubungan sempurna antar variabel bebas sehingga regresi ganda dapat dilanjutkan. Hal ini karena koefisien regresi yang dihasilkan oleh analisis regresi berganda menjadi sangat kuat sehingga dapat memberikan hasil analisis yang mewakili sifat atau pengaruh dari variabel bebas terhadap variabel terikat. Hasil uji multikolinieritas adalah sebagai berikut:

Tabel Ringkasan Hasil Uji Multikolinieritas

\begin{tabular}{|l|l|l|l|l|l|}
\hline $\begin{array}{l}\mathbf{N} \\
\mathbf{o}\end{array}$ & Variabel bebas & $\mathbf{X}_{\mathbf{1}}$ & $\mathbf{X}_{\mathbf{2}}$ & $\mathbf{V I F}$ & Ket \\
\cline { 1 - 5 } $\mathbf{1}$ & Kepemimpinan kepala madrasah $\left(\mathrm{X}_{1}\right)$ & $\mathbf{1}$ & $\mathbf{0 , 4 4 9}$ & $\mathbf{1 , 2 5 3}$ & $\begin{array}{l}\text { Tidak terjadi } \\
\text { multikolinieritas }\end{array}$ \\
\cline { 1 - 5 } $\mathbf{2}$ & Motivasi kerja guru $\left(\mathrm{X}_{2}\right)$ & $\mathbf{0 , 4 4 9}$ & $\mathbf{1}$ & $\mathbf{1 , 2 5 3}$ & \\
\hline
\end{tabular}

Sumber: Data primer yang telah diolah 


\section{PEMBAHASAN}

Hipotesis merupakan dugaan sementara atas rumusan masalah. Oleh sebab itu hipotesis harus diuji kebenaran empiriknya. Pengujian hipotesis ke 1 dan hipotesis ke 2 dalam penelitian ini menggunakan analisis regresi sederhana dengan membandingkan $t_{\text {hitung }}$ dengan t tabel, sedangkan pengujian hipotesis ke 3 menggunakan analisis regresi ganda dengan membandingkan $\mathrm{F}_{\text {hitung }}$ dengan $\mathrm{F}_{\text {tabel. }}$ Adapun hasil dari uji hipotesis dalam penelitian ini adalah sebagai berikut:

\section{a. Pengujian Hipotesis ke-1}

Pengujian hipotesis kesatu yaitu menguji apakah ada pengaruh positif antara kepemimpinan kepala madrasah terhadap kreativitas guru PNS Madrasah Tsanawiyah Negeri (MTsN) se-Kabupaten Madiun tahun pelajaran 2017/2018. Untuk menguji hipotesis tersebut digunakan uji Regresi Sederhana. Uji regresi sederhana digunakan karena untuk mencari pengaruh antara satu variabel bebas terhadap variabel terikat. Selain itu, ada hubungan linier antara variabel bebas terhadap variabel terikat sehingga analisisnya menggunakan analisis Regresi Linier. Data diolah dengan bantuan program komputer SPSS statistic version 18. Berikut adalah tabel ringkasan hasil Regresi Sederhana:

Tabel Ringkasan Hasil Analisis Regresi Sederhana $\left(\mathrm{X}_{\mathbf{1}}-\mathrm{Y}\right)$

\begin{tabular}{|l|l|l|l|l|l|l|l|}
\hline Sumber & Koefisien & $\mathbf{R}$ & $\mathbf{r}^{\mathbf{2}}$ & $\mathbf{T}$ & $\mathbf{t}_{\mathbf{o}, \mathbf{o}}$ & $\boldsymbol{P}$ & Ket \\
\hline Kepemimpinan kepala madrasah & 55,516 & 0,473 & 0,330 & 5,332 & 1,645 & 0,000 & $\mathrm{H}_{0}$ ditolak \\
& 0,283 & & & & & & \\
\hline
\end{tabular}

Sumber: Data primer yang telah diolah

1) Persamaan Garis Regresi

Perhitungan menggunakan program SPSS statistic version 18 didapatkan besarnya konstanta $\left(b_{o}\right)=55,516$ dan nilai koefisien regresi $(b)=0,283$, dan $\mathrm{X}$ adalah variabel independen. Persamaan regresi linier sederhananya sebagai berikut:

$$
\begin{aligned}
Y=b_{o} & +b X \\
& =0,283+55,516
\end{aligned}
$$

\section{2) Koefisien Korelasi (r) dan Koefisien Determinan $\left(r^{2}\right)$}

Berdasarkan hasil analisis dengan menggunakan SPSS statistic version 18 menunjukkan bahwa koefisien regresi sebesar 0,283. Harga koefisien (r) sebesar o,473 dan koefisien determinasi $\left(\mathrm{r}^{2}\right)$ sebesar 0,330. Hal ini menunjukkan bahwa kreativitas guru 
Madrasah Tsanawiyah Negeri se-Kabupaten Madiun tahun pelajaran 2017/2018 33,0\% ditentukan oleh variabel kepemimpinan kepala madrasah ditentukan oleh indikator seperti memiliki visi yang jelas dan kuat, memiliki harapan tinggi, memiliki aktivitas pemberdayaan sumber daya manusia, mendorong pemanfaatan waktu, mendayagunakan berbagai sumber belajar dan melibatkan seluruh warga sekolah, memanfaatkan informasi untuk mengarahkan perencanaan pembelajaran, melakukan evaluasi dan perbaikan secara berkesinambungan. ${ }^{22}$ Sedangkan 67,0\% variabel kreativitas guru ditentukan variabel lain.

\section{3) Pengujian Signifikansi Regresi Sederhana}

Uji signifikansi menggunakan uji t. Hasil uji t diperoleh nilai $t_{\text {hitung }}$ sebesar 5,332 sedangkan nilai $t_{\text {tabel }}$ sebesar 1,645 pada taraf signifikansi $5 \%$ maka 5,332 $>1,645\left(t_{\text {hitung }}>t_{\text {tabel }}\right)$ sehingga dapat disimpulkan $\mathrm{H}_{\mathrm{o}}$ ditolak, berarti kepemimpinan kepala madrasah mempunyai pengaruh positif dan signifikan tehadap kreativitas guru.

b. Pengujian Hipotesis ke-2

Pengujian hipotesis kedua yaitu menguji apakah ada pengaruh positif dan signifikan antara motivasi kerja guru terhadap kreativitas guru PNS Madrasah Tsanawiyah Negeri (MTsN) se-Kabupaten Madiun tahun pelajaran 2017/2018. Data diolah dengan bantuan program komputer SPSS statistic version 18. Berikut adalah tabel ringkasan hasil Regresi Sederhana:

\section{Tabel Ringkasan Hasil Analisis Regresi Sederhana $\left(\mathrm{X}_{2}-\mathrm{Y}\right)$}

\begin{tabular}{|l|l|l|l|l|l|l|l|}
\hline Sumber & Koefisien & $\mathbf{R}$ & $\mathbf{r}^{\mathbf{2}}$ & $\mathbf{T}$ & $\mathbf{\mathbf { o } _ { \mathbf { o } , \mathbf { o } }}$ & $\boldsymbol{P}$ & Ket \\
\hline Motivasi kerja guru & 31,761 & 0,397 & 0,257 & 5,516 & 1,645 & 0,000 & Ho ditolak \\
& 0,395 & & & & & & \\
\hline
\end{tabular}

Sumber: Data primer yang telah diolah

\section{1) Persamaan Garis Regresi}

Perhitungan menggunakan program SPSS statistic version 18 didapatkan besarnya konstanta $\left(b_{o}\right)=31,761$ dan nilai koefisien regresi $(b)=0,395$, dan X adalah variabel independen. ${ }^{23}$ sehingga persamaan regresi linier sederhananya sebagai berikut:

$$
\begin{aligned}
Y & =b_{o}+b X \\
& =0,395+31,761
\end{aligned}
$$

22 Mulyasa, Manajemen dan Kepemimpinan Kepala Sekolah (Bandung: Remaja Rosdakarya, 2004), 17. 23 Duwi Priyatno, 47. 


\section{2) Koefisien Korelasi ( $\mathbf{r})$ dan Koefisien Determinan $\left(\mathbf{r}^{2}\right)$}

Berdasarkan hasil analisis dengan menggunakan SPSS statistic version 18 menunjukkan bahwa koefisien regresi sebesar 0,395. Harga koefisien korelasi ( $\mathrm{r}$ ) sebesar 0,397 dan koefisien determinasi $\left(\mathrm{r}^{2}\right)$ sebesar 0,257. Hal ini menunjukkan bahwa kreativitas guru PNS Madrasah Tsanawiyah Negeri se-Kabupaten Madiun tahun pelajaran 2017/2018 $\mathbf{2 5 , 7 \%}$ ditentukan oleh variabel motivasi kerja guru dengan indikator. Sedangkan 74,3\% variabel kreativitas guru ditentukan variabel lain.

\section{3) Pengujian Signifikansi Regresi Sederhana}

Pengujian signifikansi dalam penelitian ini bertujuan untuk mengetahui tingkat keberartian variabel motivasi kerja guru terhadap kreativitas guru. Uji signifikansi menggunakan uji t. Hasil uji t diperoleh nilai $t_{\text {hitung }}$ sebesar 5,516 sedangkan nilai $t_{\text {tabel }}$ sebesar 1,645 pada taraf signifikansi 5\% maka 5,516 > 1,645 $\left(t_{\text {hitung }}>t_{\text {tabel }}\right)$ sehingga dapat disimpulkan $\mathrm{H}_{\mathrm{o}}$ ditolak, berarti motivasi kerja guru mempunyai pengaruh positif dan signifikan terhadap kreativitas guru.

\section{c. Pengujian Hipotesis ke-3}

Hipotesis ketiga yaitu menguji apakah ada pengaruh antara kepemimpinan kepala madrasah dan motivasi kerja guru secara bersama-sama terhadap kreativitas guru PNS Madrasah Tsanawiyah Negeri (MTsN) se-Kabupaten Madiun tshun pelaran 2017/2018. Untuk menguji hipotesis tersebut data diolah dengan bantuan program komputer SPSS statistic version 18. Berikut adalah tabel ringkasan hasil Regresi Ganda antara $\mathrm{X}_{1}$ dan $\mathrm{X}_{2}$ terhadap $\mathrm{Y}$ :

Tabel Ringkasan Hasil Analisis Regresi Ganda $\left(\mathrm{X}_{1} \& \mathrm{X}_{\mathbf{2}}-\mathrm{Y}\right)$

\begin{tabular}{|l|l|l|l|l|l|l|l|}
\hline Sumber & Koefisien & $\mathbf{R}$ & $\mathbf{r}^{\mathbf{2}}$ & $\mathbf{F}$ & $\mathbf{f}_{\mathbf{0}, \mathbf{0}}$ & $\boldsymbol{P}$ & Kt \\
\hline Konstanta & 32,249 & 0,397 & 0,257 & 15,123 & 3,04 & 0,000 & Ho ditolak \\
Kepemimpinan Kepala Madrasah & 0,300 & & & & & & \\
Motivasi Kerja & 0,398 & & & & & & \\
\hline
\end{tabular}

Sumber: Data primer yang telah diolah

\section{1) Persamaan Garis Regresi}

Berdasarkan tabel di atas, selanjutnya dapat digunakan untuk melakukan pengujian hipotesis ke-3, yaitu dengan perhitungan menggunakan program SPSS statistic version 18 didapatkan besarnya konstanta $(K)=32,249$ dan nilai koefisien regresi $\left(a_{1}\right)=0,300$ dan $\left(a_{2}\right)=$ 0,398 sehingga persamaan regresi linier sederhananya sebagai berikut:

$Y=a_{1} X+a_{2} X+k$ 


$$
=0,300 X_{1}+0,398 X_{2}+32,249
$$

\section{2) Koefisien Korelasi (r) dan Koefisien Determinan $\left(\mathbf{r}^{2}\right)$}

Berdasarkan hasil analisis dengan menggunakan SPSS statistic version 18 menunjukkan bahwa harga koefisien korelasi sebesar 0,397 dan harga koefisien determinasi $\left(r^{2}\right)$ sebesar 0,257. Hal ini berarti bahwa kreativitas guru PNS Madrasah Tsanawiyah Negeri (MTsN) se-Kabupaten Madiun tahun pelajaran 2017/2018 25,7\% dipengaruhi oleh variabel kepemimpinan kepala madrasah dan motivasi kerja guru, sedangkan 74,3\% dipengaruhi variabel lain baik secara internal seperti rasio, bakat khusus, perasaan, dan intuisi. Maupun eksternal seperti latar belakang pendidikan guru, pelatihan-pelatihan guru, pengalaman mengajar guru, dan faktor kesejahteraan guru.

\section{3) Pengujian Signifikansi Regresi Ganda}

Pengujian signifikansi dalam penelitian ini bertujuan untuk mengetahui tingkat keberartian variabel kepemimpinan kepala madrasah dan motivasi kerja guru terhadap kreativitas guru MTsN se-Kabupaten Madiun Tahun Pelajaran 2017-2018. Uji signifikansi menggunakan uji F. Berdasarkan hasil uji F diperoleh $F_{\text {hitung }}$ sebesar 15,123. Jika dibandingkan dengan nilai $F_{\text {tabel }}$ sebesar 3,040 pada taraf signifikan 5\%, maka 15,123> 3,040 sehingga kesimpulannya $\mathrm{H}_{\mathrm{o}}$ ditolak yang berarti terdapat pengaruh positif dan signifikan secara bersama-sama antara kepemimpinan kepala madrasah dan motivasi kerja guru terhadap kreativitas guru.

\section{KESIMPULAN}

Kesimpulan yang dapat diambil sebagai berikut:

1. Terdapat pengaruh yang positif dan signifikan antara kepemimpinan kepala madrasah terhadap kreativitas guru Pegawai Negeri Sipil MTsN se-Kabupaten Madiun tahun pelajaran 2017/2018. Hal ini ditunjukkan dengan hasil uji t diperoleh harga $t_{\text {hitung }}$ sebesar 5,332 lebih besar dari nilai $t_{\text {tabel }}$ sebesar 1,645 pada taraf signifikansi 5\% dengan koefisien determinan o,330 sehingga dapat disimpulkan kreativitas guru dipengaruhi oleh kepemimpinan kepala madrasah sebesar 33,0\% dan sisanya 67,0 \% ditentukan variabel lain baik internal seperti rasio, bakat khusus, perasaan, dan intuisi. Maupun eksternal seperti latar belakang pendidikan guru, pelatihan-pelatihan guru, pengalaman mengajar guru, dan faktor kesejahteraan guru. 
2. Terdapat pengaruh yang positif dan signifikan antara motivasi kerja guru terhadap kreativitas guru Pegawai Negeri Sipil MTsN se-Kabupaten Madiun tahun pelajaran 2017/2018. Hal ini ditunjukkan dengan hasil uji t diperoleh harga $t_{\text {hitung }}$ sebesar 5,516 lebih besar dari nilai $t_{\text {tabel }}$ sebesar 1,645 pada taraf signifikansi 5\% dengan koefisien determinan 0,257 sehingga dapat disimpulkan kreativitas guru dipengaruhi oleh motivasi kerja sebesar 25,7\% dan sisanya 74,3\% variabel kreativitas guru ditentukan variabel lain baik internal seperti rasio, bakat khusus, perasaan, dan intuisi. Maupun eksternal seperti latar belakang pendidikan guru, pelatihan-pelatihan guru, pengalaman mengajar guru, dan faktor kesejahteraan guru.

3. Terdapat pengaruh yang positif dan signifikan antara kepemimpinan kepala madrasah dan motivasi kerja guru terhadap kreativitas guru Pegawai Negeri Sipil MTsN se-Kabupaten Madiun tahun pelajaran 2017/2018 yang ditunjukkan dengan hasil uji F yaitu nilai Fhitung lebih besar dari Ftabel $(15,123$ > 3,040). Dan pada taraf signifikan 5\% dengan koefisien determinan 0,257 sehingga dapat disimpulkan bahwa kreativitas guru dipengaruhi oleh kepemimpinan kepala madrasah dan motivasi kerja guru sebesar 25,7\%. Data hasil penelitian ini menunjukkan bahwa kepemimpinan kepala madrasah dan motivasi kerja menyumbang sebesar $25,7 \%$ dan sisanya $74,3 \%$ dipengaruhi variabel lain baik secara internal seperti rasio, bakat khusus, perasaan, dan intuisi. Maupun eksternal seperti latar belakang pendidikan guru, pelatihan-pelatihan guru, pengalaman mengajar guru, dan faktor kesejahteraan guru. 
Southeast Asian Journal of Islamic Education Management 1 (1) 2020)

\section{DAFTAR PUSTAKA}

Abdurahman, Maman. Dasar-dasar Metode Statistik untuk Penelitian. Bandung: Pustaka Setia. 2011.

Agung, Iskandar. Meningkatkan Kreativitas Pembelajaran Bagi Guru. Jakarta Timur: Bestari Buana Murni. 2010.

Arikunto, Suharsimi. Dasar-dasar Evaluasi Pendidikan. Jakarta: PT Bumi Aksara. 2000.

Asmani, Jamal Ma’mur. Sudahkah Anda Menjadi Guru Berkarisma. Yogjakarta: Diva Prees. 2015.

Damayanti, Sukses Menjadi Guru Humoris dan Idola. Yogjakarta: Araska. 2016.

Handoko, T. Hani. Manajemen Personalia dan Sumber Daya Manusia. Yogyakarta: BPFE Yogyakarta, 2001.

Hasan, Chalidjah. Dimensi-dimensi Psikologi Pendidikan. Surabaya: al-Ikhlas. 1994.

$\begin{array}{llllll}\text { Kompas. } & \text { Nasib } & \text { guru } & \text { Sertifikasi. } & 27 & \text { Oktober }\end{array}$ http://edisi.kompas.com/read/2017/10/27/16340051/sertifikasi-guru-bagaimana-nasibnyakini-. di akses tanggal 21 Januari 2018.

Latuconsina, Hudaya. Pendidikan Kreatif. Jakarta: Gramedia Pustaka Utama. 2014.

Makmun. Psikologi Pendidikan. Bandung: Remaja Rosdakarya. 2005.

Mulyasa, Manajemen Berbasis Sekolah. Bandung: PT Remaja Rosdakarya. 2012.

Mulyasa. Manajemen dan Kepemimpinan Kepala Sekolah. Jakarta: Bumi Aksara. 2013.

Mulyasa. Menjadi Guru Profesional. Bandung: Remaja Rosdakarya. 2008.

Munandar, Utami. Kreativitas dan Keberbakatan: Strategi Mewujudkan Potensi Kreatif dan Bakat. Jakarta: Gramedia Pustaka. 2002

Observasi, kegiatan Pembelajaran di MTsN Balerejo, MTsN Kare, MTsN Sidorejo, Observasi, Madiun, pada bulan Januari 2018.

Samana, A. Profesionalisme Keguruan. Yogyakarta: Kanisius, 1994.

Sanjaya, Wina. Kurikulum dan Pembelajaran. Jakarta: Kencana, 2010.

Sukardi, Metodologi Penelitian. Jakarta: Raja Grafindo. 2013. 
Southeast Asian Journal of Islamic Education Management 1 (1) 2020)

Sutrisno, Edy. Manajemen Sumber Daya Manusia. Jakarta: Kencana. 2017.

Syah, Muhibbin. Psikologi Belajar. Jakarta: Raja Grafindo Persada. 2003. 